\title{
Succinic Acid Production across Candidate Lignocellulosic Biorefinery Feedstocks
}

\author{
Yifeng Xu' ${ }^{1}$, Jamie L. Foster ${ }^{2}$, James P. Muir ${ }^{3}$, Byron L. Burson ${ }^{4}$, Russell W. Jessup ${ }^{*}$ \\ ${ }^{1}$ Department of Soil \& Crop Sciences, Texas A\&M University, College Station, TX, USA \\ ${ }^{2}$ Texas A\&M AgriLife Research Station, Beeville, TX, USA \\ ${ }^{3}$ Texas A\&M AgriLife Research Center, Stephenville, TX, USA \\ ${ }^{4}$ USDA-ARS, Crop Germplasm Research Unit, Southern Plains Agricultural Research Center, College Station, TX, USA \\ Email: *rjessup@tamu.edu
}

How to cite this paper: $\mathrm{Xu}, \mathrm{Y}$.F., Foster, J.L., Muir, J.P., Burson, B.L. and Jessup, R.W. (2018) Succinic Acid Production across Candidate Lignocellulosic Biorefinery Feedstocks. American Journal of Plant Sciences, 9, 2141-2153.

https://doi.org/10.4236/ajps.2018.911155

Received: September 12, 2018

Accepted: October 8, 2018

Published: October 11, 2018

Copyright (C) 2018 by authors and Scientific Research Publishing Inc. This work is licensed under the Creative Commons Attribution International License (CC BY 4.0).

http://creativecommons.org/licenses/by/4.0/

\begin{abstract}
Non-food lignocellulosic crops with both high biomass yields and superior adaptation to marginal lands have significant potential as biofuel feedstocks that can replace fossil fuels. Deployment of dedicated crops into single biofuels, however, has been reduced by conversion technology costs and low petroleum prices. Integrated biorefinery strategies, in which value-added coproducts are generated in conjunction with biofuels, by comparison offer opportunities to overcome this economic disadvantage. The objective of this research was to evaluate succinic acid accumulation across candidate lignocellulosic feedstocks. Feedstock entries included pearl millet $\mathrm{x}$ napiergrass hybrids ("PMN"; Pennisetum glaucum [L.] R. Br. $\times$ P. purpureum Schumach.), napiergrass ( $P$. purpureum Schumach.), annual sorghum (Sorghum bicolor [L.] Moench), pearl millet (P. glaucum [L.] R. Br.), perennial sorghum (Sorghum spp.), switchgrass (Panicum virgatum L.), sunn hemp (Crotalaria juncea L.), giant miscanthus (Miscanthus $\times$ giganteus J. M. Greef \& Deuter) and energy cane (Saccharum spp. L.). Replicated field plots, as well as an independent greenhouse trial, were characterized for succinic acid content. The PMN, napiergrass, sunn hemp and energy cane entries had greater $(P \leq 0.05)$ succinic acid yields, up to $556 \mathrm{~kg} \cdot \mathrm{ha}^{-1}$, in field trials. Napiergrass and PMN entries similarly had higher succinic acid yields under greenhouse conditions; however, irrigation treatments did not alter succinic acid accumulation in this study. Napiergrass, PMN, and energy cane thus are promising biorefinery feedstocks.
\end{abstract}

\section{Keywords}

Biofuels, Biorefinery, Succinic Acid 


\section{Introduction}

\subsection{Succinic Acid}

Succinic acid is among the Department of Energy's top value-added chemicals from biomass [1]. It is a four-carbon dicarboxylic acid that can be utilized as a key building block for a broad range of products: biodegradable plastics, cosmetics, food ingredients and pharmaceutical products. The petrochemical synthesis of succinic acid involves hydrogenation of 1,4-dicarboxylic unsaturated $\mathrm{C}_{4}$ acids or anhydrides, oxidation of 1,4-butanediol, hydrogenation of maleic anhydride to succinic anhydride and then hydration of succinic anhydride to succinic acid [2]. Alternatively, bioprodution of succinic acid from renewable feedstocks is possible through fermentation of glucose using an engineered form of either Anaerobiospirillum succiniciproducens or Eschericia coli has been reported [1]. Recent research has found that high yields and productivities of succinic acid bio-manufacturing can be achieved using Actinobacillus succinogenes $130 \mathrm{Z}$ in a custom, and continuous fermentation step, which makes bio-succinic acid a promising value-added chemical in integrated biorefineries [3]. Increased synthesis and bioaccumulation of such carboxylic acids have also been reported when $\mathrm{C}_{4}$ perennial grasses are subject to abiotic stress such as drought [4]. This finding indicates opportunity for direct isolation of succinic acid as a coproduct from biomass feedstocks without typical lignocellulosic hydrolysis and upgrading from glucose in competition for use with primary biofuels (bioethanol, etc.). In order to investigate this potential, the objectives of this research were to: 1) evaluate succinic acid content and total yield across candidate lignocellulosic feedstocks under field conditions, and 2) characterize the impact of deficit irrigation upon succinic acid bioaccumulation across candidate lignocellulosic feedstocks under greenhouse conditions.

\subsection{Feedstocks}

\subsubsection{Napiergrass}

Napiergrass (Pennisetum purpureum Schumach.) is a high biomass perennial that is used primarily as a forage grass throughout the tropical and subtropical regions of the world [5]. As a species native to areas of equatorial Africa where annual precipitation exceeds $1000 \mathrm{~mm}$ [6], napiergrass's germplasm varies for cold tolerance. Biomass yields of napiergrass have a wide range dependent on location, cultivar, years since planting, water and soil fertility input levels, and other abiotic factors. Napiergrass biomass production in Gainesville, FL ranged from 24.1 to $27.3 \mathrm{Mg} \mathrm{ha}^{-1} \mathrm{y}^{-1}$ in 1986 and 18.5 to $21.1 \mathrm{Mg} \mathrm{ha}^{-1} \mathrm{y}^{-1}$ in 1987 [7]. A study conducted in Tifton, GA for four consecutive years indicated that the napiergrass lines Merkeron and N51 produced at least $25 \mathrm{Mg} \mathrm{ha}^{-1} \mathrm{y}^{-1}$ biomass for the first $2 \mathrm{y}$ [8]. Trials conducted in Thailand showed that biomass yield ranged from 27.1 to $58.4 \mathrm{Mg} \mathrm{ha}^{-1} \mathrm{y}^{-1}$ among eight napiergrass accessions [9]. In Kenya, the average biomass yield of 10 napiergrass accessions was $22.4 \mathrm{Mg} \mathrm{ha}^{-1}$ when grown at a semi-arid lowland site and $36.8 \mathrm{Mg} \mathrm{ha}^{-1}$ on a wet highland location 
[10].

\subsubsection{Pearl Millet}

Pearl millet (Pennisetum glaucum [L.] R. Br.) is an annual diploid (2n $=2 x=$ 14). It originated in northern Africa in an area extending from western Sudan to Senegal [11]. Pearl millet is mainly used as a grain crop in India, Pakistan, and Africa; however, its main use in the USA, Australia, and parts of South America is as forage [12]. There is an increasing interest in planting this grass as a grain crop to feed livestock in the USA [12]. Although grain production of pearl millet hybrid is not comparable to sorghum and maize hybrids, as a forage crop its yield can exceed sorghum and maize [13]. Pearl millet is also more drought tolerant and suited to marginal lands than maize [14]. One study comparing forage yield among sorghum, millet and corn cultivars found greater biomass yield in pearl millet $\left(12,285 \mathrm{~kg} \cdot \mathrm{ha}^{-1}\right)$ than sorghum cultivars Jumbo, Speed feed, and Sugar graze [15].

\subsection{3. "PMN" (Pearl Millet-Napiergrass)}

Napiergrass $(2 \mathrm{n}=4 \mathrm{x}=28)$ can be crossed with pearl millet (Pennisetum glaucum [L.] R. Br.) $(2 \mathrm{n}=2 x=14)$ to produce interspecific triploid hybrids $(2 \mathrm{n}=3 \mathrm{x}$ $=21$ ) that have the chemical composition of pearl millet and biomass yield potential of napiergrass [5]. Pearl millet-napiergrass ("PMN"; Pennisetum glaucum [L.] R. Br. $\times$ P. purpureum Schumach.) hybrids are also candidate biofuel feedstocks because they are sterile $F_{1}$ plants that can be planted via seed and produce high biomass yields. Pearl millet-napiergrass can have both high yields of perennial grasses like energycane (Saccharum spp.) and comparatively large seed of annual grasses such as sorghum (Sorghum bicolor [L.] Moench) [16]. Seed production of pearl millet-napiergrass can approach that of commercial forage sorghum [17]. The yield and size of PMN seed therefore make its establishment more cost-effective than the vegetative reproduction of perennial species such as energycane and giant miscanthus (Miscanthus $x$ giganteus) [18]. Establishment year yields of PMN reach $37 \mathrm{Mg} \mathrm{DM} \mathrm{ha}^{-1} \mathrm{y}^{-1}$ in subtropical climates and $38 \mathrm{Mg}$ $\mathrm{DM} \mathrm{ha}^{-1} \mathrm{y}^{-1}$ in Zimbabwe [19] [20].

\subsubsection{Switchgrass}

Switchgrass (Panicum virgatum L.) is a perennial grass indigenous to North America. Switchgrass can be utilized as a forage crop, either grazed or harvested for silage and hay [21]. In the USA, recent research on herbaceous energy crop production systems has included switchgrass [22] due to its wide adaptation, genetic diversity, biomass yield potential, and suitability for marginal land. Among switchgrass cultivars, "Alamo" has greater biomass yield and broader adaptability than others in Virginia, Alabama and Texas [23]. For sustainable biomass production, $\mathrm{N}$ application $\left(168 \mathrm{~kg} \mathrm{~N} \mathrm{ha}^{-1} \mathrm{y}^{-1}\right)$, but not always $P$ application and row spacing, is necessary for switchgrass to maximize biomass production in low- $\mathrm{N}$ soils [24]. Other research has also indicated that $\mathrm{N}$ application in- 
fluences biomass yield of switchgrass [25] [26].

\subsubsection{Miscanthus}

Giant miscanthus (Miscanthus $\times$ giganteus J. M. Greef \& Deuter) is a perennial $\mathrm{C}_{4}$ grass native to Asia. It is a triploid interspecific hybrid between $M$. sinensis Andersson (a diploid species) and M. sacchariflorus (Maxim.) Hack (a tetraploid species) [27]. This triploid warm-season $\mathrm{C}_{4}$ grass is unable to produce viable seed and must be propagated by rhizomes. High average biomass yields, excluding the two establishment years, range from 22.0 to $35.4 \mathrm{Mg} \mathrm{ha}^{-1} \mathrm{y}^{-1}$ in the central USA [28]. However, this level of high biomass yield cannot be obtained in low-rainfall Texas [29]. Side-by-side experiments conducted in the USA comparing biomass yield of switchgrass and giant miscanthus can be found in some recent research [30] [31].

\subsubsection{Energy Cane}

Sugarcane (Saccharum L. spp.) is a perennial grass cultured mainly for sucrose production [32]. As a perennial bioenergy crop derived from sugarcane, energy cane is derived from sugarcane but selected for greater fiber concentration, biomass yields, and cold tolerance [33]. Improved cold tolerance allows energy cane to be grown in areas further north than sugarcane in the USA (Florida, Louisiana, and Texas) [34]. More importantly, its improved adaptation to marginal land gives it more potential as a lignocellulosic biomass feedstock [35]. Biomass yields of energy cane are comparable to other lignocellulose feedstocks [19] [36].

\subsubsection{Sorghum}

Sorghum is an important crop used mainly for grain and forage production, and it is now being evaluated as a bioenergy crop [37]. Its diverse utilization, including bioenergy potential of grain sorghum, sweet sorghum and high biomass cellulosic sorghum (including bagasse, residue, high-biomass sorghums and photoperiod sensitive sorghums), is significant [37]. Among many traits of forage sorghum that may impact forage quality, one trait is controlled by brown midrib (BMR) mutants and influences forage quality [38]. Chemically induced BMR mutants in sorghum were first induced in 1978 and can reduce lignin concentration as much as $51 \%$ in stems and $25 \%$ in leaves [39]. With reduced lignin concentration, BMR sorghum cultivars have greater forage digestibility [38]. More importantly from a bioenergy perspective, this attribute could improve overall cellulosic ethanol conversion efficiencies when recalcitrance caused by lignin is mitigated. Biomass and estimated ethanol yields among sweet sorghum, BMR sorghum cultivars, and several perennial grasses indicated that the greatest biomass yield and ethanol production can be achieved from sweet sorghum [40].

\subsubsection{Sunn Hemp}

Sunn hemp (Crotalaria juncea L.) is a legume native to India and is used as a soil-improving crop, a green manure, and as livestock feed [41]. Due to its rapid growth rate, ability to fix $\mathrm{N}$, and capacity to mitigate plant-root nematodes, the 
cultivar "Tropic Sun" is used as a green manure for rotation with many row crops [42]. High biomass yield to prevent soil erosion and $\mathrm{N}$ released to subsequent crops make sunn hemp an alternative to winter legumes in warm temperate regions [43]. Its potential to replace winter legumes as a cover crop has focused on dry biomass, $\mathrm{N}$ accumulation, and decomposition of residue [43] [44] [45]. Rapid accumulation of sunn hemp biomass was reported in one study, in which it produced $10.7 \mathrm{Mg} \mathrm{DM} \mathrm{ha}^{-1}$ after only 12 weeks of growth [46].

\section{Materials and Methods}

\subsection{Plant Materials}

Twelve feedstock entries spanning seven grass species and one legume species were included in both field and greenhouse trials (Table 1).

\subsection{Field Trial}

In May 2016, replicated plots $(n=3)$ were planted in a completely randomized design in College Station, Beeville, and Stephenville, TX. The College Station location $\left(30^{\circ} 32^{\prime} \mathrm{N}, 96^{\circ} 26^{\prime} \mathrm{W}\right.$; elevation $\left.81 \mathrm{~m}\right)$ was on a Weswood silty clay loam ( $\mathrm{pH}$ 8.0). The Beeville location $\left(28^{\circ} 27^{\prime} \mathrm{N}, 97^{\circ} 42^{\prime} \mathrm{W}\right.$; elevation $70 \mathrm{~m}$ ) was on a Parrita sandy clay loam ( $\mathrm{pH} 7.2)$. The Stephenville location $\left(34^{\circ} 17^{\prime} \mathrm{N}, 96^{\circ} 12^{\prime} \mathrm{W}\right.$; elevation $370 \mathrm{~m}$ ) was on a Windthorst fine sandy loam ( $\mathrm{pH}$ 6.8). The Beeville, College Station, and Stephenville sites were in the United States Department of Agriculture plant hardiness zones 9 a, 8 b, and 8 a respectively. The growing season included 2538, 2858, and 2460 Growing Degree Days (GDD; ${ }^{\circ} \mathrm{C}$ ), as well as 602,1105 , and $655 \mathrm{~mm}$ of total water inputs (irrigation plus precipitation) at the respective Beeville, College Station, and Stephenville locations. Each cultivar

Table 1. Plant accessions used in field and greenhouse trials for succinic acid quantification.

\begin{tabular}{cc}
\hline Species & Identification \\
\hline Napiergrass & PMN10TX13 \\
Napiergrass & Merkeron \\
Napiergrass & PEPU 09FL03 \\
BMR sorghum & PEPU 09FL01 \\
Annual sorghum & SDH2942 \\
BMR Pearl millet & SX-17 \\
Perennial sorghum & Exceed \\
Switchgrass & PSH 09TX15 \\
Sunn hemp & Alamo \\
Giant miscanthus & Tropical Isle \\
Energy cane & (Mxg) \\
& (Unknown accession) \\
\hline
\end{tabular}


was planted in three plots $(3 \mathrm{~m} \times 3 \mathrm{~m})$ with four, 3-m rows. Random green leaf samples collected from field trials at two dates (September and November 2016) were used for succinic acid content assays. Leaf samples were packed in dry ice before being frozen and were kept frozen $\left(-20^{\circ} \mathrm{C}\right)$ until analyzed. Measurement of intracellular concentrations of succinic acid [47] was conducted using the Succinate (Succinic Acid) Colorimetric Assay kit (Biovision, Milpitas, CA, USA), according to manufacturer's instructions. Absorbance measurements were made at $450 \mathrm{~nm}$.

\subsection{Greenhouse Trial}

To evaluate the drought induction of succinic acid accumulation, all entries were planted in a greenhouse trial in May 2016. Replicated 11L pots $(n=3)$ were planted in completely randomized design. A potting media mix (Sunshine Redi-Earth Plug \& Seed Potting Mix) was used. Plants were maintained in the greenhouse for 3 mo before drought treatments were imposed to allow acclimation of plants to greenhouse conditions. During this period, greenhouse temperatures were kept below $38^{\circ} \mathrm{C}$, no supplemental lighting was utilized, plants were monitored daily and watered as required to maintain field capacity, and no supplemental fertilization applications were made. Treatments included a well-irrigated control and deficit irrigation regime, which were initiated in August 2016. Soil volumetric water contents (SWC) were measured daily using a soil moisture meter (FieldScout TDR 100; Spectrum Technologies, Aurora IL, USA). Well-irrigated plants were watered to maintain soil water content at field capacity. In the drought stress treatment, plants were not irrigated until the volumetric soil moisture content dropped below 15\%. Greenhouse temperatures were again maintained below $38^{\circ} \mathrm{C}$, and neither supplemental lighting nor fertilization was incorporated. Leaf samples of plants from each pot were collected on November 15, 2016. Leaf samples were again immediately packed in dry ice upon harvest and kept frozen $\left(-20^{\circ} \mathrm{C}\right)$ until analyzed. Intracellular succinic acid concentrations were quantified using the Succinate (Succinic Acid) Colorimetric Assay kit (Biovision, Milpitas, CA, USA) according to manufacturer's instructions, and absorbance measurements were made at $450 \mathrm{~nm}$.

\subsection{Data Analysis and Statistics}

The field trial statistical model consisted of location, harvest and plant entry in a three-factorial arrangement looking at three-way interactions and, if those were not significant $(P \leq 0.05)$, at simple effects. The greenhouse statistical model consisted of irrigation level and plant entry in a two-factorial arrangement looking at two-way interactions and, if those were not significant, at simple effects. Data collected was submitted to analysis of variance and, where appropriate, multiple means separated using All Pair, Tukey's HSD with JMP software (JMP Pro12, Statistical Analysis System, Cary NC, USA). Differences were considered significant at $P \leq 0.05$. 


\section{Results and Discussion}

\subsection{Field Trials}

In the field trials, succinic acid concentrations did not vary across sampling dates (Table 2). However, differences among feedstock entries, locations, and both 2-way and 3-way interactions were identified. Across September samples, BMR pearl millet succinic acid concentration was the highest among feedstock entries at Stephenville and College Station, the two more northern locations (Table 3). Two napiergrass entries (PEPU 09FL03, PEPU 09FL01) were equivalent to the BMR pearl millet at Stephenville, but another napiergrass (Merkeron) was equivalent to it at College Station. Across November samples, there were no differences for succinic acid concentration among feedstock entries at all locations (Table 3). The highest average succinic acid concentration among feedstocks was observed at Beeville in September and November (Table 3); however, large differences in biomass yields resulted in succinic acid yields being more informative. Stephenville had the greatest total succinic acid yield among three locations (Table 4). At Stephenville, PEPU 09FL03 had the highest succinic acid yield, while PMN and energy cane were equivalent. PMN had the greatest succinic acid yield $\left(\mathrm{kg} \cdot \mathrm{ha}^{-1}\right)$ at College Station and Beeville (Table 4). Sunn hemp succinic acid yield data was missing from Beeville because small ruminant herbivory significantly impacted field plot biomass yields.

\subsection{Greenhouse Trial}

In the greenhouse trial, succinic acid concentrations did not vary across irrigation treatments. However, feedstock entries differed in their response to irrigation levels. PMN and Merkeron had the highest succinic acid concentration under deficit irrigation, while the non-BMR annual sorghum had the lowest succinic acid concentration (Table 5). Under non-deficit irrigation, Merkeron, PEPU 09FL03, PEPU 09FL01 and switchgrass had the highest succinic acid concentrations, and the BMR annual sorghum had the lowest concentration (Table 5). Pearl millet samples were not taken from the well-watered treatment because of poor stand establishment from the seeds.

Table 2. Analysis of variance of succinic acid concentration for field experiment.

\begin{tabular}{|c|c|}
\hline & Succinate \\
\hline $\operatorname{loc} c^{Y}$ & $* * * Z$ \\
\hline time $e^{\mathrm{X}}$ & ns \\
\hline $\operatorname{trt}^{\mathrm{W}}$ & $* * *$ \\
\hline loc time & $* * *$ \\
\hline $\operatorname{loc}^{\star} \operatorname{trt}$ & $* * *$ \\
\hline time $^{\star} \operatorname{trt}$ & $* * *$ \\
\hline $\operatorname{loc}^{*} \operatorname{time}^{*} \operatorname{trt}$ & $* * *$ \\
\hline
\end{tabular}

${ }^{\mathrm{z}} \mathrm{NS}$ (nonsignificant) or significant at $\left.P \leq 0.05\left(^{*}\right), 0.01{ }^{* *}\right)$, or $\left.0.001{ }^{* * *}\right) .{ }^{\mathrm{y}}$ Three locations. ${ }^{\mathrm{x}}$ Two harvesting time. ${ }^{\mathrm{W}}$ Plant entries. 
Table 3. Succinic acid ( $\mathrm{g} \cdot \mathrm{kg}^{-1}$ leaf) concentration of samples collected in September and November at Stephenville, College Station, and Beeville, Texas.

\begin{tabular}{|c|c|c|c|c|c|c|}
\hline \multirow{3}{*}{ Entry } & \multicolumn{6}{|c|}{ Succinic acid $\left(\mathrm{g} \cdot \mathrm{kg}^{-1}\right)$} \\
\hline & \multicolumn{2}{|c|}{ Stephenville } & \multicolumn{2}{|c|}{ College Station } & \multicolumn{2}{|c|}{ Beeville } \\
\hline & Sept & Nov & Sept & Nov & Sept & Nov \\
\hline PMN 10TX13 & $0.3 c^{Z}$ & $7.3 \mathrm{a}$ & $4.3 \mathrm{abc}$ & $5.1 \mathrm{a}$ & $11.3 \mathrm{a}$ & $8.0 \mathrm{a}$ \\
\hline Merkeron & $3.8 \mathrm{bc}$ & $8.3 \mathrm{a}$ & $5.2 \mathrm{a}$ & $5.4 \mathrm{a}$ & $10.9 \mathrm{a}$ & $7.6 \mathrm{a}$ \\
\hline PEPU 09FL03 & $7.4 \mathrm{a}$ & $8.2 \mathrm{a}$ & $4.7 \mathrm{ab}$ & $5.9 \mathrm{a}$ & $12.0 \mathrm{a}$ & $9.3 \mathrm{a}$ \\
\hline PEPU 09FL01 & $8.4 \mathrm{a}$ & $8.5 \mathrm{a}$ & $4.3 \mathrm{abc}$ & $5.6 \mathrm{a}$ & $11.1 \mathrm{a}$ & $9.0 \mathrm{a}$ \\
\hline BMR Sorghum & $6.1 \mathrm{ab}$ & $5.6 \mathrm{a}$ & $1.9 \mathrm{c}$ & $4.5 \mathrm{a}$ & $11.8 \mathrm{a}$ & $6.7 \mathrm{a}$ \\
\hline SX-17 & $1.6 \mathrm{c}$ & $6.9 \mathrm{a}$ & $3.1 \mathrm{abc}$ & $3.8 \mathrm{a}$ & $10.1 \mathrm{a}$ & $7.7 \mathrm{a}$ \\
\hline BMR pearl millet & $8.8 \mathrm{a}$ & $6.4 \mathrm{a}$ & $5.5 \mathrm{a}$ & $4.0 \mathrm{a}$ & $10.7 \mathrm{a}$ & $7.3 \mathrm{a}$ \\
\hline PSH 09TX15 & $0.5 \mathrm{c}$ & $8.0 \mathrm{a}$ & $2.8 \mathrm{abc}$ & $3.5 \mathrm{a}$ & $12.2 \mathrm{a}$ & $9.0 \mathrm{a}$ \\
\hline Alamo switchgrass & $6.3 \mathrm{ab}$ & $7.3 \mathrm{a}$ & $3.4 \mathrm{abc}$ & $4.9 \mathrm{a}$ & $12.0 \mathrm{a}$ & $8.9 \mathrm{a}$ \\
\hline Tropical isle Sunn Hemp & $6 \mathrm{ab}$ & $5.7 \mathrm{a}$ & $1.7 \mathrm{bc}$ & $2.5 \mathrm{a}$ & $9.3 \mathrm{ab}$ & $8.3 \mathrm{a}$ \\
\hline Giant miscanthus (Mxg) & $0.3 \mathrm{c}$ & $5.6 \mathrm{a}$ & $3.2 \mathrm{abc}$ & $3.6 \mathrm{a}$ & $2.6 \mathrm{~b}$ & $6.3 \mathrm{a}$ \\
\hline Energy cane & $6.1 \mathrm{ab}$ & $7.2 \mathrm{a}$ & $3.9 \mathrm{abc}$ & $3.7 \mathrm{a}$ & $8.1 \mathrm{ab}$ & $6.1 \mathrm{a}$ \\
\hline
\end{tabular}

$\mathrm{Z}$ Means within a column under each main factor followed by the same letter are not significantly different according to All Pairs $(P>0.05)$, Tukey HSD.

Table 4. Succinic acid yield $\left(\mathrm{kg} \cdot \mathrm{ha}^{-1}\right)$ in November 2016 at Stephenville, College Station and Beeville, Texas.

\begin{tabular}{cccc}
\hline \multicolumn{2}{c}{ Entry } & \multicolumn{3}{c}{ Means } \\
\hline Stephenville & College Station & Beeville \\
\hline PMN 10TX13 & $236 \mathrm{a}^{\mathrm{Z}}$ & $370 \mathrm{a}$ & $556 \mathrm{a}$ \\
Merkeron & $188 \mathrm{ab}$ & $77 \mathrm{~b}$ & $145 \mathrm{~b}$ \\
PEPU 09FL03 & $271 \mathrm{a}$ & $65 \mathrm{~b}$ & $143 \mathrm{~b}$ \\
PEPU 09FL01 & $153 \mathrm{ab}$ & $33 \mathrm{~b}$ & $116 \mathrm{~b}$ \\
BMR sorghum & $74 \mathrm{ab}$ & $13 \mathrm{~b}$ & $44 \mathrm{~b}$ \\
SX-17 & $111 \mathrm{ab}$ & $17 \mathrm{~b}$ & $99 \mathrm{~b}$ \\
BMR pearl millet & $53 \mathrm{ab}$ & $3 \mathrm{~b}$ & $3 \mathrm{~b}$ \\
PSH 09TX15 & $84 \mathrm{ab}$ & $13 \mathrm{~b}$ & $89 \mathrm{~b}$ \\
Alamo switchgrass & $87 \mathrm{ab}$ & $29 \mathrm{~b}$ & $55 \mathrm{~b}$ \\
Tropical Isle Sunn Hemp & $198 \mathrm{ab}$ & $81 \mathrm{~b}$ & - \\
Giant miscanthus (Mxg) & $24 \mathrm{~b}$ & $8 \mathrm{~b}$ & $12 \mathrm{~b}$ \\
Energy cane & $248 \mathrm{a}$ & $50 \mathrm{~b}$ & $86 \mathrm{~b}$
\end{tabular}

$\mathrm{Z}$ Means within a column under each main factor followed by the same letter are not significantly different according to All Pairs ( $P>0.05)$, Tukey HSD. 
Table 5. Succinic acid (g. $\mathrm{kg}^{-1}$ leaf) concentration of greenhouse samples.

\begin{tabular}{ccc}
\hline & \multicolumn{2}{c}{ Succinate $\left(\mathrm{g} \cdot \mathrm{kg}^{-1}\right)$} \\
\cline { 2 - 3 } Entry & Deficit irrigation & Non-deficit irrigation \\
PMN 10TX13 & $11.1 \mathrm{a}^{\mathrm{Z}}$ & $8.0 \mathrm{ab}$ \\
PEPU 09FL03 & $10.1 \mathrm{a}$ & $9.9 \mathrm{a}$ \\
PEPU 09FL01 & $9.4 \mathrm{ab}$ & $11.1 \mathrm{a}$ \\
BMR Sorghum & $9.3 \mathrm{ab}$ & $10.9 \mathrm{a}$ \\
SX-17 & $9.5 \mathrm{ab}$ & $0.8 \mathrm{~b}$ \\
BMR pearl millet & $1.5 \mathrm{c}$ & $9.0 \mathrm{ab}$ \\
PSH 09TX15 & $10.2 \mathrm{abc}$ & \\
Alamo switchgrass & $3.1 \mathrm{bc}$ & $6.9 \mathrm{ab}$ \\
Tropical isle Sunn Hemp & $8.2 \mathrm{abc}$ & $10.4 \mathrm{a}$ \\
Giant miscanthus (Mxg) & $4.6 \mathrm{abc}$ & $6.9 \mathrm{ab}$ \\
Energy cane & $4.5 \mathrm{abc}$ & $5.3 \mathrm{ab}$ \\
Grand mean & $4.3 \mathrm{abc}$ & $7.8 \mathrm{ab}$ \\
\hline
\end{tabular}

$\mathrm{Z}$ Means within a column under each main factor followed by the same letter are not significantly different according to All Pairs $(P>0.05)$, Tukey HSD.

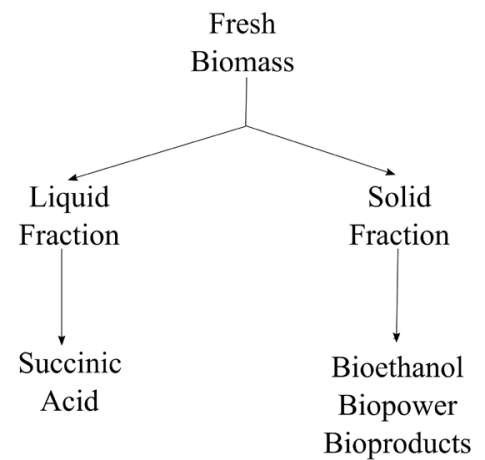

Figure 1. Illustration of a conceptual integrated biorefinery producing ethanol, biopower, succinic acid, and bioproducts.

\section{Conclusion}

The greatest succinic acid yields were recovered from PMN, napiergrass, sunn hemp and energy cane. Our results demonstrated that biomass yield for feedstocks had a much greater effect on total succinic acid yield than succinic acid concentration within feedstocks. Economic profitability of biofuel strategies can therefore be improved when candidate feedstocks are processed through integrated biorefineries including both primary biofuels as well as succinic acid. A conceptual biorefinery incorporating succinic acid could include the following stages: 1) succinic acid extracted from the liquid fraction prior to ethanol fermentation, 2) bioethanol conversion from cellulose and hemicellulose fractions, 
3) biopower from the residual lignin fraction, and 4) mineral bioproducts (biosilica, plant nutrients) from the remaining ash fraction (Figure 1). However, the methods needed to isolate succinic acid from lignocellulosic biomass are largely uncharacterized. Future research to optimize succinic acid extraction methodologies is thus warranted.

\section{Conflicts of Interest}

The authors declare no conflicts of interest regarding the publication of this paper.

\section{References}

[1] Werpy, T., Petersen, G., Aden, A., Bozell, J., Holladay, J., White, J., Manheim, A., Eliot, D., Lasure, L. and Jones, S. (2004) Top Value Added Chemicals from Biomass. Volume 1-Results of Screening for Potential Candidates from Sugars and Synthesis Gas. DTIC Document.

[2] Pinazo, J.M., Domine, M.E., Parvulescu, V. and Petru, F. (2015) Sustainability Metrics for Succinic Acid production: A Comparison between Biomass-Based and Petrochemical Routes. Catalysis Today, 239, 17-24. https://doi.org/10.1016/j.cattod.2014.05.035

[3] Bradfield, M.F., Mohagheghi, A., Salvachúa, D., Smith, H., Black, B.A., Dowe, N., Beckham, G.T. and Nicol, W. (2015) Continuous Succinic Acid Production by Actinobacillus succinogenes on Xylose-Enriched Hydrolysate. Biotechnology for Biofuels, 8, 181. https://doi.org/10.1186/s13068-015-0363-3

[4] Du, H., Wang, Z., Yu, W. and Huang, B. (2012) Metabolic Responses of Hybrid Bermudagrass to Short-Term and Long-Term Drought Stress. Journal of the American Society for Horticultural Science, 137, 411-420.

[5] Hanna, W.W., Chaparro, C.J., Mathews, B.W., Burns, J.C., Sollenberger, L.E. and Carpenter, J.R. (2004) Perennial Pennisetums. In: Moser, L.E., Burson, B.L. and Sollenberger, L.E., Eds., Warm-Season $\left(C_{4}\right)$ Grasses, Agronomy Monograph 45, American Society of Agronomy, Crop Science Society of America and Soil Science Society of America, Madison, 503-535.

[6] Bogdan, A.V. (1977) Tropical Pasture and Fodder Plant. Longman, London, 475.

[7] Woodard, K.R. and Prine, G.M. (1991) Forage Yield and Nutritive Value of Elephantgrass as Affected by Harvest Frequency and Genotype. Agronomy Journal, 83, 541-546. https://doi.org/10.2134/agronj1991.00021962008300030005x

[8] Knoll, J.E., Anderson, W.F., Strickland, T.C., Hubbard, R.K. and Malik, R. (2012) Low-Input Production of Biomass from Perennial Grasses in the Coastal Plain of Georgia, USA. BioEnergy Research, 5, 206-214.

https://doi.org/10.1007/s12155-011-9122-x

[9] Rengsirikul, K., Ishii, Y., Kangvansaichol, K., Sripichitt, P., Punsuvon, V., Vaithanomsat, P., Nakamanee, G. and Tudsri, S. (2013) Biomass Yield, Chemical Composition and Potential Ethanol Yields of 8 Cultivars of Napiergrass (Pennisetum purpureum Schumach.) Harvested 3-Monthly in Central Thailand. Journal of Sustainable Bioenergy Systems, 3, 107-112. https://doi.org/10.4236/jsbs.2013.32015

[10] Mwendia, S.W., Yunusa, I.A.M., Sindel, B.M., Whalley, R.D.B. and Kariuki, I.W. (2017) Assessment of Napier Grass Accessions in Lowland and Highland Tropical Environments in East Africa: Productivity and Forage Quality. Experimental Agri- 
culture, 53, 27-43. https://doi.org/10.1017/S001447971600003X

[11] Harlan, J.R. and de Wet, J.M.J. (1971) Toward a Rational Classification of Cultivated Plants. Taxon, 20, 509-517. https://doi.org/10.2307/1218252

[12] Hanna, W.W., Baltensperger, D.D. and Seetharam, A. (2004) Pearl Millet and Other Millets. In: Moser, L.E., Burson, B.L. and Sollenberger, L.E., Eds., Warm-Season $\left(C_{4}\right)$ Grasses, Agronomy Monograph 45, American Society of Agronomy, Crop Science Society of America and Soil Science Society of America, Madison, 537-560.

[13] Burton, G.W. (1983) Breeding Pearl Millet. In: Janick, J., Ed., Plant Breeding Reviews, Springer, Boston, 162-182. https://doi.org/10.1007/978-1-4684-8896-8_6

[14] Basavaraj, G., Rao, P.P., Bhagavatula, S. and Ahmed, W. (2010) Availability and Utilization of Pearl Millet in India. SAT eJournal, 8, 1-6. http://ejournal.icrisat.org/Volume8/IMPI/Availability_and_utilization.pdf

[15] Jahansouz, M.R., Afshar, R.K., Heidari, H. and Hashemi, M. (2014) Evaluation of Yield and Quality of Sorghum and Millet as Alternative Forage Crops to Corn under Normal and Deficit Irrigation Regimes. Jordan Journal of Agricultural Sciences, 10, 699-715. https://doi.org/10.12816/0031747

[16] Dowling, C.D., Burson, B.L., Foster, J.L., Tarpley, L. and Jessup, R.W. (2013) Confirmation of Pearl Millet-Napiergrass Hybrids Using EST-Derived Simple Sequence Repeat (SSR) Markers. American Journal of Plant Sciences, 4, 1004-1012. https://doi.org/10.4236/ajps.2013.45124

[17] Osgood, R.V., Hanna, W.W. and Tew, T.L. (1997) Hybrid Seed Production of Pearl Millet $\times$ Napiergrass Triploid Hybrids. Crop Science, 37, 998-999. https://doi.org/10.2135/cropsci1997.0011183X003700030049x

[18] Jessup, R.W. and Dowling, C.D. (2015) “Seeded-Yet-Sterile" Perennial Grasses: Towards Sustainable and Non-Invasive Biofuel Feedstocks. In: Quinn, L.D., Matlaga, D.P. and Barney, J.N., Eds., Bioenergy and Biological Invasions. Ecological, Agronomic and Policy Perspectives on Minimizing Risk, CABI, Boston, 97-112.

[19] Woodard, K.R. and Prine, G.M. (1993) Dry Matter Accumulation of Elephantgrass, Energycane, and Elephantmillet in a Subtropical Climate. Crop Science, 33, 818-824. https://doi.org/10.2135/cropsci1993.0011183X003300040038x

[20] Gupta, S.C. and Mhere, O. (1997) Identification of Superior Pearl Millet by Napier Hybrids and Napiers in Zimbabwe. African Crop Science Journal, 5, 229-237. https://doi.org/10.4314/acsj.v5i3.27840

[21] Parrish, D.J. and Fike, J.H. (2005) The Biology and Agronomy of Switchgrass for Biofuels. Critical Reviews in Plant Sciences, 24, 423-459. https://doi.org/10.1080/07352680500316433

[22] Kiniry, J.R., Cassida, K.A., Hussey, M.A., Muir, J.P., Ocumpaugh, W.R., Read, J.C., Reed, R.L., Sanderson, M.A., Venuto, B.C. and Williams, J.R. (2005) Switchgrass Simulation by the ALMANAC Model at Diverse Sites in the Southern US. Biomass and Bioenergy, 29, 419-425. https://doi.org/10.1016/j.biombioe.2005.06.003

[23] Sanderson, M.A., Reed, R.L., McLaughlin, S.B., Wullschleger, S.D., Conger, B.V., Parrish, D.J., Wolf, D.D., Taliaferro, C., Hopkins, A.A., Ocumpaugh, W.R. and Hussey, M.A. (1996) Switchgrass as a Sustainable Bioenergy Crop. Bioresource Technology, 56, 83-93. https://doi.org/10.1016/0960-8524(95)00176-X

[24] Muir, J.P., Sanderson, M.A., Ocumpaugh, W.R., Jones, R.M. and Reed, R.L. (2001) Biomass Production of "Alamo" Switchgrass in Response to Nitrogen, Phosphorus, and Row Spacing. Agronomy Journal, 93, 896-901. https://doi.org/10.2134/agronj2001.934896x 
[25] Guretzky, J.A., Biermacher, J.T., Cook, B.J., Kering, M.K. and Mosali, J. (2011) Switchgrass for Forage and Bioenergy: Harvest and Nitrogen Rate Effects on Biomass Yields and Nutrient Composition. Plant and Soil, 339, 69-81. https://doi.org/10.1007/s11104-010-0376-4

[26] Heaton, E., Voigt, T. and Long, S.P. (2004) A Quantitative Review Comparing the Yields of Two Candidate $\mathrm{C}_{4}$ Perennial Biomass Crops in Relation to Nitrogen, Temperature and Water. Biomass and Bioenergy, 27, 21-30. https://doi.org/10.1016/j.biombioe.2003.10.005

[27] Pyter, R., Voigt, T., Heaton, E., Dohleman, F. and Long, S. (2007) Growing Giant Miscanthus in Illinois. http://miscanthus.illinois.edu/wp-content/uploads/growersguide.pdf

[28] Pyter, R., Heaton, E., Dohleman, F., Voigt, T. and Long, S. (2009) Agronomic Experiences with Miscanthus $x$ giganteus in Illinois, USA. In: Mielenz, J.R. Ed., Biofuels. Methods and Protocols, Humana Press, Totowa, 41-52. https://doi.org/10.1007/978-1-60761-214-8_3

[29] Kiniry, J.R., Johnson, M.V.V., Bruckerhoff, S.B., Kaiser, J.U., Cordsiemon, R.L. and Harmel, R.D. (2012) Clash of the Titans: Comparing Productivity via Radiation Use Efficiency for Two Grass Giants of the Biofuel Field. BioEnergy Research, 5, 41-48. https://doi.org/10.1007/s12155-011-9116-8

[30] Kering, M.K., Butler, T.J., Biermacher, J.T. and Guretzky, J.A. (2012) Biomass Yield and Nutrient Removal Rates of Perennial Grasses under Nitrogen Fertilization. BioEnergy Research, 5, 61-70. https://doi.org/10.1007/s12155-011-9167-x

[31] Palmer, I.E., Gehl, R.J., Ranney, T.G., Touchell, D. and George, N. (2014) Biomass Yield, Nitrogen Response, and Nutrient Uptake of Perennial Bioenergy Grasses in North Carolina. Biomass and Bioenergy, 63, 218-228. https://doi.org/10.1016/j.biombioe.2014.02.016

[32] Legendre, B.L. and Burner, D.M. (1995) Biomass Production of Sugarcane Cultivars and Early-Generation Hybrids. Biomass and Bioenergy, 8, 55-61. https://doi.org/10.1016/0961-9534(95)00014-X

[33] Knoll, J.E., Anderson, W.F., Richard Jr., E.P., Doran-Peterson, J., Baldwin, B., Hale, A.L. and Viator, R.P. (2013) Harvest Date Effects on Biomass Quality and Ethanol Yield of New Energycane (Saccharum hyb.) Genotypes in the Southeast USA. Biomass and Bioenergy, 56, 147-156. https://doi.org/10.1016/j.biombioe.2013.04.018

[34] Salassi, M.E., Brown, K., Hilbun, B.M., Deliberto, M.A., Gravois, K.A., Mark, T.B. and Falconer, L.L. (2014) Farm-Scale Cost of Producing Perennial Energy Cane as a Biofuel Feedstock. BioEnergy Research, 7, 609-619. https://doi.org/10.1007/s12155-013-9390-8

[35] Shields, S. and Boopathy, R. (2011) Ethanol Production from Lignocellulosic Biomass of Energy Cane. International Biodeterioration \& Biodegradation, 65, 142-146. https://doi.org/10.1016/j.ibiod.2010.10.006

[36] Fedenko, J.R., Erickson, J.E., Woodard, K.R., Sollenberger, L.E., Vendramini, J.M., Gilbert, R.A., Helsel, Z.R. and Peter, G.F. (2013) Biomass Production and Composition of Perennial Grasses Grown for Bioenergy in a Subtropical Climate across Florida, USA. BioEnergy Research, 6, 1082-1093.

https://doi.org/10.1007/s12155-013-9342-3

[37] Rooney, W.L., Blumenthal, J., Bean, B. and Mullet, J.E. (2007) Designing Sorghum as a Dedicated Bioenergy Feedstock. Biofuels, Bioproducts and Biorefining, 1, 147-157. https://doi.org/10.1002/bbb.15

[38] Pedersen, J.F. and Rooney, W.L. (2004) Sorghums. In: Moser, L.E., Burson, B.L. and 
Sollenberger, L.E., Eds., Warm-Season $\left(C_{4}\right)$ Grasses, Agronomy Monograph 45, American Society of Agronomy, Crop Science Society of America and Soil Science Society of America, Madison, 1057-1079.

[39] Porter, K.S., Axtell, J.D., Lechtenberg, V.L. and Colenbrander, V.F. (1978) Phenotype, Fiber Composition, and in Vitro Dry Matter Disappearance of Chemically Induced Brown Midrib (bmr) Mutants of Sorghum. Crop Science, 18, 205-208. https://doi.org/10.2135/cropsci1978.0011183X001800020002x

[40] Propheter, J.L., Staggenborg, S.A., Wu, X. and Wang, D. (2010) Performance of Annual and Perennial Biofuel Crops: Yield during the First Two Years. Agronomy Journal, 102, 806-814. https://doi.org/10.2134/agronj2009.0301

[41] Bin, J. (1983) Utilization of Green Manure for Raising Soil Fertility in China. Soil Science, 135, 65. https://doi.org/10.1097/00010694-198301000-00013

[42] Rotar, P.P. and Joy, R.J. (1983) “Tropic Sun” Sunn Hemp; Crotalaria juncea L. http://hdl.handle.net/10125/15089

[43] Mansoer, Z., Reeves, D.W. and Wood, C. (1997) Suitability of Sunn Hemp as an Alternative Late-Summer Legume Cover Crop. Soil Science Society of America Journal, 61, 246-253. https://doi.org/10.2136/sssaj1997.03615995006100010034x

[44] Balkcom, K.S. and Reeves, D.W. (2005) Sunn-Hemp Utilized as a Legume Cover Crop for Corn Production. Agronomy Journal, 97, 26-31. https://doi.org/10.2134/agronj2005.0026

[45] Schomberg, H.H., Martini, N.L., Diaz-Perez, J.C., Phatak, S.C., Balkcom, K.S. and Bhardwaj, H.L. (2007) Potential for Using Sunn Hemp as a Source of Biomass and Nitrogen for the Piedmont and Coastal Plain Regions of the Southeastern USA. Agronomy Journal, 99, 1448-1457. https://doi.org/10.2134/agronj2006.0294

[46] Cantrell, K.B., Bauer, P.J. and Ro, K.S. (2010) Utilization of Summer Legumes as Bioenergy Feedstocks. Biomass and Bioenergy, 34, 1961-1967.

https://doi.org/10.1016/j.biombioe.2010.08.005

[47] Li, Y.H., Woo, S.H., Choi, D.H. and Cho, E.H. (2015) Succinate Causes $\alpha$-SMA Production through GPR91 Activation in Hepatic Stellate Cells. Biochemical and Biophysical Research Communications, 463, 853-858. https://doi.org/10.1016/j.bbrc.2015.06.023 